Gothic Pride 



\title{
Gothic PRIDE
}

\author{
The Story of Building a \\ Great Cathedral in Newark
}

BRIAN REGAN

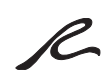

Rivergate Books

AN IMPRINT OF RUTGERS UNIVERSITY PRESS

NEW BRUNSWICK, NEW JERSEY, AND LONDON 


\section{Library of Congress Cataloging-in-Publication Data \\ Regan, Brian.}

Gothic pride : the story of building a great cathedral in Newark / Brian Regan.

$$
\text { p. } \mathrm{cm} \text {. }
$$

Includes bibliographical references and index.

ISBN 978-0-8I35-5288-o (hardcover : alk. paper)-

$$
\text { ISBN 978-0-8I345346-7 (e-book) }
$$

I. Cathedral of the Sacred Heart (Newark, N.J.) 2. Gothic revival

(Architecture)—New Jersey—Newark. 3. Basilicas—New Jersey—Newark.

4. Newark (N.J.)-Buildings, structures, etc. I. Title.

$$
\begin{gathered}
\text { NA5235.N63R44 } 20 \mathrm{I} 2 \\
726.609749 ' 32-\mathrm{dc} 23 \\
2011033053
\end{gathered}
$$

A British Cataloging-in-Publication record for this book is available from the British Library.

Publication of Gothic Pride is made possible in part by generous financial support from the Most Reverend Peter Leo Gerety, Archbishop Emeritus of the Archdiocese of Newark; Thomas P. Higgins; the New Jersey Catholic

Historical Commission; Eugene O'Hara; and Charles Scribner III.

Additional support was provided by Pamela L. and Robert W. Ferguson Jr., John Pearson, and Shirley Smoyak.

\section{Copyright (C) 2012 by Brian Regan}

All rights reserved

No part of this book may be reproduced or utilized in any form or by any means, electronic or mechanical, or by any information storage and retrieval system, without written permission from the publisher. Please contact Rutgers University Press, Io6 Somerset Street, New Brunswick, NJ ०890I. The only exception to this prohibition is "fair use" as defined by U.S. copyright law.

Visit our website: http://rutgerspress.rutgers.edu Manufactured in the United States of America 
for

MY MOTHER AND FATHER 
